Article

\title{
Preparation, Mechanical and Thermal Properties of Cement Board with Expanded Perlite Based Composite Phase Change Material for Improving Buildings Thermal Behavior
}

\author{
Rongda Ye, Xiaoming Fang, Zhengguo Zhang * and Xuenong Gao \\ Received: 23 September 2015 ; Accepted: 2 November 2015 ; Published: 13 November 2015 \\ Academic Editors: Luisa F. Cabeza and Inés Fernández \\ Key Laboratory of Enhanced Heat Transfer and Energy Conservation, the Ministry of Education, \\ School of Chemistry and Chemical Engineering, South China University of Technology, Guangzhou 510640, \\ China; ye.rongda@mail.scut.edu.cn (R.Y.); cexmfang@scut.edu.cn (X.F.); cexngao@scut.edu.cn (X.G.) \\ * Correspondence: cezhang@scut.edu.cn; Tel.: +86-20-8711-2845; Fax: +86-20-8711-3870
}

\begin{abstract}
Here we demonstrate the mechanical properties, thermal conductivity, and thermal energy storage performance of construction elements made of cement and form-stable PCM-Rubitherm ${ }^{\circledR}$ RT 28 HC (RT28)/expanded perlite (EP) composite phase change materials (PCMs). The composite PCMs were prepared by adsorbing RT28 into the pores of EP, in which the mass fraction of RT28 should be limited to be no more than $40 \mathrm{wt} \%$. The adsorbed RT28 is observed to be uniformly confined into the pores of EP. The phase change temperatures of the RT28/EP composite PCMs are very close to that of the pure RT28. The apparent density and compression strength of the composite cubes increase linearly with the mass fraction of RT28. Compared with the thermal conductivity of the boards composed of cement and EP, the thermal conductivities of the composite boards containing RT28 increase by $15 \%-35 \%$ with the mass fraction increasing of RT28. The cubic test rooms that consist of six boards were built to evaluate the thermal energy storage performance, it is found that the maximum temperature different between the outside surface of the top board with the indoor temperature using the composite boards is $13.3^{\circ} \mathrm{C}$ higher than that of the boards containing no RT28. The thermal mass increase of the built environment due to the application of composite boards can contribute to improving the indoor thermal comfort and reducing the energy consumption in the buildings.
\end{abstract}

Keywords: expanded perlite; composite phase change material; building energy conservation

\section{Introduction}

Buildings are one of the leading sectors in the energy consumption in the developed countries. Taking the European Union as an example, the buildings sector consumes around $40 \%$ of the total fossil energy and produces nearly $40 \%$ of the total $\mathrm{CO}_{2}$ emissions. Most of it is due to the increase in the living standard and in occupants' comfort demands, mainly for heating and cooling [1]. Improving the energy efficiency of buildings has a significant benefit for energy-saving and emission-reduction on the earth. In particular, nowadays the trend in the commercial buildings is to decrease the wall thickness to reduce the materials consumed, the transport costs, and the construction time. The main disadvantage of these lightweight buildings is the low thermal mass, resulting in large temperature fluctuations indoors. A phase change material (PCM) can absorb or release a large quantity of latent heat when it changes phase from solid state to liquid state or vice versa, and has been commonly used in thermal energy storage systems [2-5]. The integration of a PCM in building ceilings, walls, and floors to store significant amounts of thermal energy 
can compensate for the small storage capacity of the lightweight buildings and thus decrease the frequency of internal air temperature swings, leading to an improvement in the human comfort and a reduction in the energy consumption for the buildings.

Since 1982, the incorporation of PCMs into building fabrics has been investigated as a potential technology for minimizing the energy consumptions in buildings [6-8]. The selection of PCMs is almost directed towards the use of organic materials in an effort to avoid some of the problems inherent in inorganic materials, such as the need for special container due to their corrosivity, tendency of super cooling, segregation, etc. Up to now, three general methods have been proposed to integrate organic PCMs into construction elements [9-11], which are the direction immersion of conventional wallboards into molten PCMs [12-16], the integration of microencapsulated PCMs with ordinary building materials [17-21], and the combination of building materials with a shape-stabilized PCM that is usually prepared by blending an organic PCM with a supporting material [22-24]. Although the first one is simple and low cost, the impregnated wallboards are inflammable owing to the diffusion of the liquid PCMs to the surfaces of the wallboards, especially after the PCMs experienced several heating-cooling cycles. The second one suffers from the complicated polymerization processes and the high costs related to the microencapsulation of PCMs. Compared with the two mentioned methods, the third one has the advantages of simple process, low cost, and a large variety of supporting matrices available, such as high density polyethylene, expanded graphite, bentonite, and so on [25-32].

Expanded Perlite (EP), a light-weight (unit volume weight: $0.05-0.30 \mathrm{~g} / \mathrm{mL}$ ), odorless, and heat expanded volcanic mineral, has been commonly used as the ultra-light-weight building material to improve the structure of buildings because of its excellent heat insulation capacity (thermal conductivity rate: $0.03-0.05 \mathrm{kcal} / \mathrm{mh}^{\circ} \mathrm{C}$ ) [33], environmentally safety, and abundant availability. The properties of high porosity, large surface area, low sound transmission, excellent fire-resistance, and low moisture retention make EP to be a good and cheap supporting matrix for preparing form-stable composite PCMs. Karaipekli and Sari groups [34-36] prepared several kinds of EP-based composite PCMs including the capric-myristic acid (CA-MA)/EP, CA/EP, lauric acid (LA)/EP, paraffin/EP and fatty acid esters/EP composites, the thermal properties, thermal reliability and the thermal conductivity of the composite PCMs are determined. The maximum PCMs absorptions of EP are obtained without melted PCMs seepage from the composites, and therefore these mixtures are described as the form-stable composites. Jiao et al. [37] have prepared the binary eutectic of LA-stearic acid (SA)/EP composite PCMs by vacuum impregnation. The structure and properties of the composite PCMs are characterized. The results show that the binary eutectic of fatty acids has been composed with the porous skeleton EP completely in a physical method. Chung et al. [38] prepared and characterized thermal properties and thermal reliability of form-stable composite PCMs composed of $n$-octadecane, expanded vermiculite, and perlite for thermal energy storage. The results showed that the prepared composite PCMs showed good compatibility between $n$-octadecane and the expanded vermiculite and pearlite, the thermal conductivities of composites were reduced, the large latent heat capacity and original phase change temperatures were maintained. Zhang et al. [39] prepared LA-palmitic acid (PA)-SA/EP composite PCMs by vacuum impregnation method. The maximum mass ratio of LA-PA-SA retained in EP was found as $55 \mathrm{wt} \%$. They found that the thermal conductivity of LA-PA-SA/EP was increased by $95 \%$ by adding $2 \mathrm{wt} \%$ expanded graphite, and the thermal energy storage/release rates were also increased. Sun et al. [40] prepared the form-stable PCMs by absorbing paraffin into EP method. Graphite as additive was added into the form-stable PCMs to improve thermal conductivity. The results showed that the thermal conductivity of the form-stable PCMs was increased as much as $192 \%$ by graphite with mass fraction of $5 \%$. Ramakrishnan et al. [41] have developed a novel thermal energy storage composite by impregnating paraffin into hydrophobic coated expanded perlite (EPO) granules. They found that no paraffin leakage was observed for novel paraffin/EPO containing $50 \%$ by weight of paraffin in the composite. Microstructural and mechanical properties were studied for the compatibility of hydrophobic coated 
PCM composite in concrete. Peng et al. [42] prepared form-stable composite PCMs for use in wallboards absorbing SA and LA eutectic mixtures into the pores of EP. The microstructure, thermal properties and the thermal reliability of the composite PCMs were characterized. Their results indicated that the maximum SA-LA absorption of the EP was as high as $65 \mathrm{wt} \%$ without any melted SA-LA leakage. A gypsum-based building wallboard containing $6 \mathrm{wt} \%$ SA-LA/EP had a low density $\left(0.924 \mathrm{~g} / \mathrm{cm}^{3}\right)$, high mechanical strength $(2.19 \mathrm{MPa})$, and remarkable heating preservation performance. Zhang et al. [43] prepared the CA-PA/EP composite PCM and fabricated the thermal-regulated gypsum boards by adding the prepared composite PCM. They found that the higher the composite PCM volume content, the smaller the thermal conductivity of the gypsum board. The bending strength and compressive strength reduced gradually with an increase of the volume fraction of the composite PCM. He et al. [44] prepared the form/stable CA-MA/EP composite PCMs, and paraffin was chosen to encapsulate the composite PCMs avoiding liquid leakage. They also prepared the temperature control mortar and studied the physical mechanical properties. As can be seen in the open literature above, different kinds of composite PCMs by absorbing organic substances into EP were widespreadly prepared, but EP-based composite phase change building materials are a few studied [41-44] until now.

Cement board that is produced by mixing up Portland cement, EP and water has wide applications in buildings such as creating a smooth surface to walls and thermal insulation structure due to the EP's higher porosity. In the current work, we focus on the incorporation of the RT28/EP composite PCM into ordinary cement to produce thermal energy storage cement board. A systematic experimental study to analyze the important effects of the thermo-mechanical properties of the produced samples, like apparent density and compression behaviors and thermal conductivity was performed. Moreover, the thermal energy storage performances of the cement boards containing different mass percentage of the RT28/EP composite PCM were evaluated. The goal of this study was to demonstrate the feasibility of using EP-based composite PCM in cement boards to increase their thermal inertia and to reduce the energy demand of the building.

\section{Experimental Section}

\subsection{Preparation and Characterization of RT28/EP Composite Phase Change Materials (PCMs)}

RT28, a kind of liquid saturated hydrocarbons, was purchased from Rubitherm GmbH corp. in Berlin, Germany. RT28 as phase change material can be applied in buildings due to its phase change temperature (about $28^{\circ} \mathrm{C}$ ) in the range of human comfort temperature (between 18 and $28^{\circ} \mathrm{C}$ ) [19]. EP was used as received. RT28/EP composite PCMs with different mass fractions of RT28 were prepared by adsorbing different amount of RT28 into the pores of EP at $60^{\circ} \mathrm{C}$ for $1 \mathrm{~h}$, respectively.

The microstructures of EP and the RT28/EP composite PCMs were observed using a scanning electron micro-scope (SEM, S-3700N, Hitachi, Kyoto, Japan), respectively. The thermal properties of RT28 and the RT28/EP composite PCMs were measured by using a differential scanning calorimeter (DSC, DSC2910, TA Instruments, New Castle, DE, USA) under $\mathrm{N}_{2}$ atmosphere. The measuring temperature ranged from -10 to $60^{\circ} \mathrm{C}$. The temperature rise rate was $5^{\circ} \mathrm{C} / \mathrm{min}$.

\subsection{Fabrication and Characterization of Cement Boards Containing RT28/EP Composites}

Four kinds of slurries were prepared by mixing cement and water with the RT28/EP composite PCMs containing 10, 20, 30 and 40 wt \% of RT28, respectively, in which all the mass ratios of the composites to cement to water are 1:1.5:2. The prepared slurries were formed into cubes by using a standard stainless steel mold (size: $70.7 \mathrm{~mm} \times 70.7 \mathrm{~mm} \times 70.7 \mathrm{~mm}$ ) to measure their mechanical properties and into boards by using a home-made stainless steel mold (size: $100 \mathrm{~mm} \times 100 \mathrm{~mm} \times 10 \mathrm{~mm}$ ) to measure their thermal conductivity and evaluate their thermal energy storage performance, respectively. Four kinds of the cubes and boards were obtained, in which the mass fractions of RT28 were calculated to be $4 \%, 8 \%, 12 \%$ and $16 \%$, respectively. For comparison 
purpose, the EP powder was also mixed with cement and water at the same mass ratio to obtain the blank slurry followed by forming into the cubes and boards using the same fabrication process.

The mechanical properties of the cubes with different mass fractions of RT28 were evaluated by measuring their compressive strength and apparent density, respectively. After being kept under a moist atmosphere for about $24 \mathrm{~h}$, all the fabricated cubes were maintained under water at $20 \pm 1{ }^{\circ} \mathrm{C}$ for 7 days. Then, some of the cubes used for measuring the compressive strength were kept under a controlled condition $\left(20 \pm 2{ }^{\circ} \mathrm{C}\right.$ in temperature and $60 \% \pm 3 \%$ in humidity) until the tests were performed on a compression-testing machine (5000 A, Jinan Shijin Group Co., Ltd., Jinan, China). Other cubes used for measuring the apparent density were dried at $100{ }^{\circ} \mathrm{C}$ until their weight didn't change. The accurate dimensions of the cubes were measured using a vernier caliper with a precision of $0.02 \mathrm{~mm}$, and their weights were measured using an analytical balance with a precision of $0.001 \mathrm{~g}$, respectively. The apparent density $(\rho)$ of the cubes was calculated by the following formula: $\rho=m / V$, respectively, where $m$ represents the weights of the cubes (unit: g), and $V$ represents the volumes of the cubes (unit: $\mathrm{cm}^{3}$ ). Conforming to Chinese Standard JGJ/T 70-2009 [45], six same samples were prepared for each compressive strength and apparent density measurements, all measurements were arithmetically averaged.

The thermal conductivity of the fabricated boards was measured at room temperature using a hot disk thermal constant analyzer (Hot Disk TPS2500, Hot Disk AB Company, Uppsala, Sweden). The measurement accuracy of the thermal conductivity was within $\pm 3 \%$. The arithmetically average value of thermal conductivity for three times measurements was chose as the experimental result for each sample.

\subsection{Thermal Energy Storage Performance Evaluation of Cement Boards Containing RT28/EP Composites}

A sketch of the experimental apparatus for testing the thermal energy storage performance of the composite boards (size: $100 \mathrm{~mm} \times 100 \mathrm{~mm} \times 10 \mathrm{~mm}$ ) is shown in Figure 1. A small test room $(100 \mathrm{~mm} \times 100 \mathrm{~mm} \times 100 \mathrm{~mm})$ that consists of 6 pieces of the boards was set up below a halogen tungsten lamp (500 W) at a distance of $35 \mathrm{~cm}$, which was used as the light source to simulate the sun. The radiation intensity was about $60 \mathrm{mw} / \mathrm{cm}^{2}$ measured by a radiometer (FZ-A type, Beijing Normal University) at the position. Two K-typed thermocouples linked to a data acquisition/switch unit (Agilent 34970A) were used to monitor the temperature variation of the test room. The thermocouples were calibrated before use, the accuracy was $\pm 0.2^{\circ} \mathrm{C}$. One of them was placed at the outside surface of the top board, and the other one was placed in the center of the test room for recording the indoor temperature. When the lamp was switched on, the temperatures at the two spots of the test room started to be monitored. After $1.5 \mathrm{~h}$, the lamp was switched off. The monitoring of the two temperatures continued until the test room cooled down to room temperature. The difference between the two temperatures varying with time was used to evaluate the performance of the boards with different mass fractions of RT28.

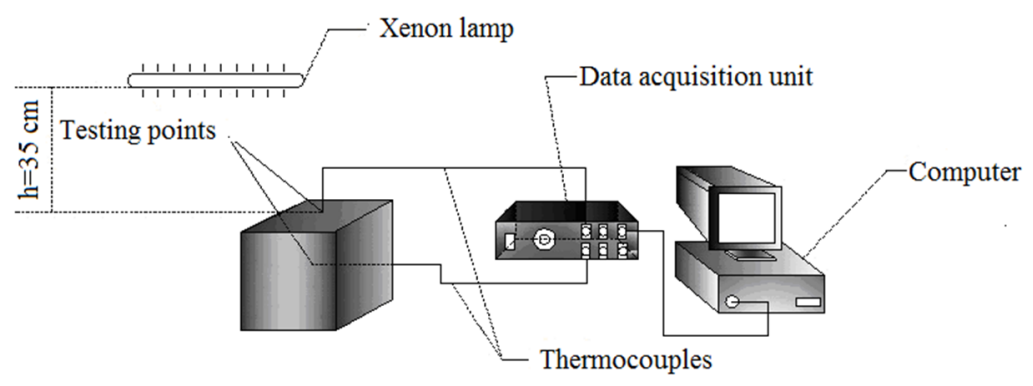

Figure 1. An experimental schematic drawing for testing energy conservation performance of composite boards. 


\section{Results and Discussion}

\subsection{Characterization of RT28/EP Composite PCMs}

In order to obtain form-stable RT28/EP composite PCMs, the maximum absorption ratio of RT28 in the EP powder should be determined. Firstly, the prepared RT28/EP composite PCMs with 40, 45 and $50 \mathrm{wt} \%$ of RT28 were placed on three piece of filter paper, respectively, followed by putting them into an oven at $60{ }^{\circ} \mathrm{C}$ for $30 \mathrm{~min}$; then, the three pieces of filter paper were taken out from the oven and cooled down to room temperature; finally, the composite PCMs were removed from the three pieces of filter paper, respectively. We checked these pieces of filter paper carefully to make sure if there were any traces of RT28 left in them due to the leakage of RT28 from the pores of EP during the heating. It is shown that there is no trace of RT28 left in the filter paper on which the RT28/EP composite PCM containing $40 \mathrm{wt} \%$ of RT 28 has been placed. However, as the mass fraction of RT28 is increased to $45 \%$, the trace of RT28 is observed, implying that the maximum adsorption ratio of RT28 in EP is around 40\%. Therefore, the RT28/EP composite PCMs containing no more than m can be considered as the form-stable composite PCMs.

EP possesses a porous structure, which makes it possible to adsorb organic PCMs. Figure 2 shows the SEM images of the RT28/EP PCMs with $30 \mathrm{wt} \%$ (a) and $40 \mathrm{wt} \%$ (b) of RT28, respectively. We can see that the adsorbed RT28 is uniformly confined into the pores of EP, and the layer of RT28 becomes thicker as its mass fraction is increased from 30 to $40 \mathrm{wt} \%$.
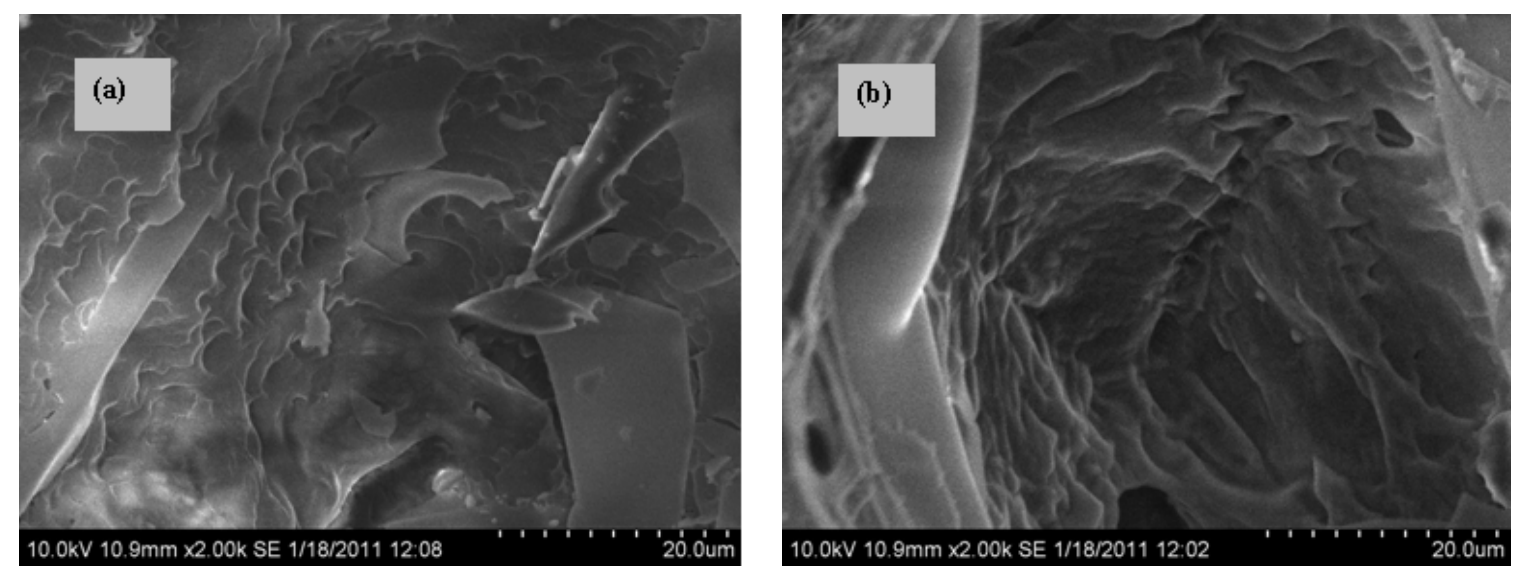

Figure 2. SEM images of the RT28/EP composite PCMs with 30 wt \% (a) and 40 wt \% (b) of RT28.

Figure 3 displays the DSC curves of EP and the RT28/EP composite PCMs with 10, 20, 30 and $40 \mathrm{wt} \%$ of RT28, respectively. The melting temperatures were measured to be $28.41,28.43,28.40$ and $28.48{ }^{\circ} \mathrm{C}$ for the composite PCMs containing 10, 20, 30 and $40 \mathrm{wt} \%$ of RT28, respectively, which are very close to $28.55{ }^{\circ} \mathrm{C}$ of RT28. RT28 has a melting latent heat as high as $197.8 \mathrm{~kJ} / \mathrm{kg}$. The melting latent heat values of the RT28/EP composite PCMs with 10\%, 20\%, 30\% and $40 \%$ of RT28 were measured to be $18.11,39.11,58.14$ and $77.44 \mathrm{~kJ} / \mathrm{kg}$, respectively. Obviously, the measured latent heat values of the composite PCMs are almost equivalent to their calculated latent heat values based on the mass fractions of RT28. It is revealed that the combination of RT28 with EP doesn't change the phase change temperature of RT28, and the maximum latent heat value of the form-stable RT28/EP composite PCMs can reach as high as $77.44 \mathrm{~kJ} / \mathrm{kg}$. 


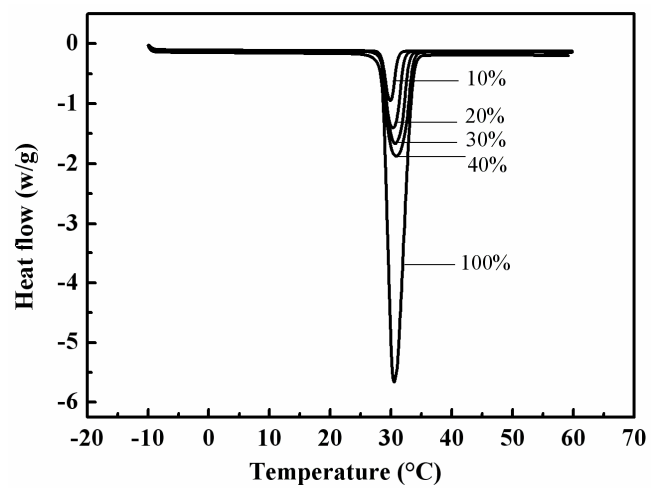

Figure 3. DSC curves of RT28 and the RT28/EP composite PCMs with 10, 20, 30 and 40 wt \% of RT28, respectively.

\subsection{Properties of Cement Cubes and Boards Containing RT28/EP Composite PCMs}

Figure 4 displays the apparent density of the four kinds of cubes made of cement and the RT28/EP composite PCMs with 10, 20, 30 and 40 wt \% of RT28, respectively, together with that of the cube made of cement and EP. The photograph of the cubes is inserted in this figure. The mass fractions of RT28 in the five kinds of cubes were calculated to be $0 \%, 4 \%, 8 \%, 12 \%$ and $16 \%$, respectively. The apparent density of the kind of cubes made of cement and EP was measured to $0.32 \mathrm{~g} / \mathrm{cm}^{3}$ on average. For the composite cubes made of cement and the RT28/EP composite PCMs, their apparent density was measured to be $0.35,0.37,0.39$ and $0.43 \mathrm{~g} / \mathrm{cm}^{3}$ as the mass fraction of RT28 in the cubes was 4, 8, 12 and 16 wt \%, respectively. The relationship between the apparent density $(\rho)$ of the cubes and the mass fraction $(x)$ of RT28 can be fitted into a linear equation: $\rho=0.32+0.0065 x$. It is revealed that the apparent density of the cubes increases linearly with the mass fraction of RT28. Since RT28 is adsorbed into the pores of EP, the volumes of the RT28/EP composites may not obviously increase with the mass fraction of RT28, but their weight definitely increases accordingly. Therefore, the apparent density of the composite cubes increases with the mass fraction of RT28. Note that the apparent density of the nine kinds of cubes is within the range from 0.3 to $0.8 \mathrm{~g} / \mathrm{cm}^{3}$, indicating that all the cubes are up to standard.

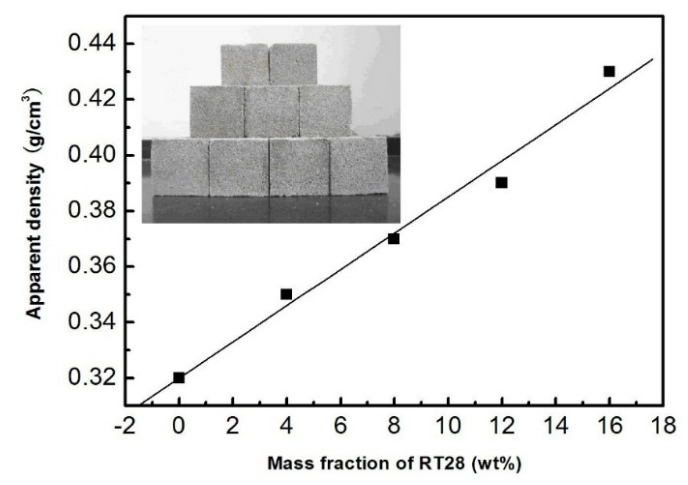

Figure 4. Relation between the apparent density of the cubes and the mass fraction of RT28 (the insert is the photograph of the cubes).

The porosity of the composite cubes made of cement and the RT28/EP composite PCMs were estimated from the bulk density, the matrix density assuming that the cement pores are filled of air which remains trapped once the cement has solidified [46]. For the composite cubes made of cement and the RT28/EP composite PCMs, their porosity was calculated to be $0.383,0.351,0.339$ and 0.313 as the mass fraction of RT28 in the cubes was 4, 8, 12 and $16 \mathrm{wt} \%$, respectively. 
Figure 5 shows the compressive strength of the five kinds of cubes containing $0 \%, 4 \%, 8 \%, 12 \%$ and $16 \%$ of RT28, respectively. The compression strength of the cube containing no RT28 is measured to be $0.35 \mathrm{MPa}$ on average. As the mass fraction of RT28 in the cubes is increased to $4 \%, 8 \%, 12 \%$ and $16 \%$, their compression strength accordingly increases to $0.39,0.47,0.51$ and $0.57 \mathrm{MPa}$, respectively. The relationship between the compression strength $(S)$ and the mass fraction $(x)$ of RT28 can be also fitted into a linear equation: $S=0.346+0.014 x$. It is indicated that the compression strength of the cubes linearly increases with the mass fraction of RT28. Note that all the compression strength of the nine kinds of cubes is more than $0.3 \mathrm{MPa}$, indicating that all the cubes are up to standard. Obviously, the addition of RT28 not only endows the building materials with the thermal energy storage performance but also improves their mechanical properties.

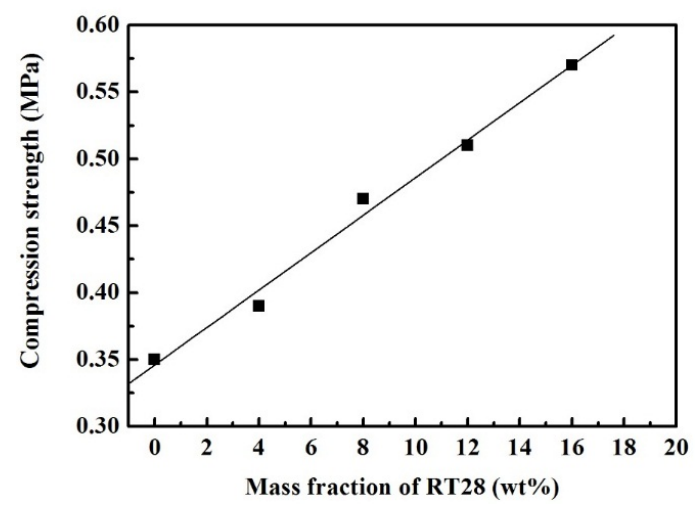

Figure 5. Relation between the compression strength of the cubes and the mass fraction of RT28.

Figure 6 shows the thermal conductivity of the five kinds of boards containing $0 \%, 4 \%, 8 \%, 12 \%$ and $16 \%$ of RT28, respectively. The photograph of the composite boards is inserted in this figure. The thermal conductivity of the board without RT28 is measured to be $0.11 \mathrm{~W} / \mathrm{m} \cdot \mathrm{K}$. As the mass fraction of RT28 in the boards is increased to $4 \%, 8 \%, 12 \%$ and $16 \%$, their thermal conductivity increases to $0.126,0.131,0.137$ and $0.149 \mathrm{~W} / \mathrm{m} \cdot \mathrm{K}$, respectively. The relationship between the thermal conductivity $(S)$ and the mass fraction $(x)$ of RT28 can be also fitted into a linear equation: $S=0.113+0.00225 x$. As the mass fraction of RT28 in the composite PCMs is increased, the pores of EP occupied by air are gradually filled with RT28. Since thermal conductivity of RT28 $(0.276 \mathrm{~W} / \mathrm{m} \cdot \mathrm{K})$ is far larger than that of air $(0.023 \mathrm{~W} / \mathrm{m} \cdot \mathrm{K})$, the thermal conductivity of the composite boards increases with the mass fraction of RT28.

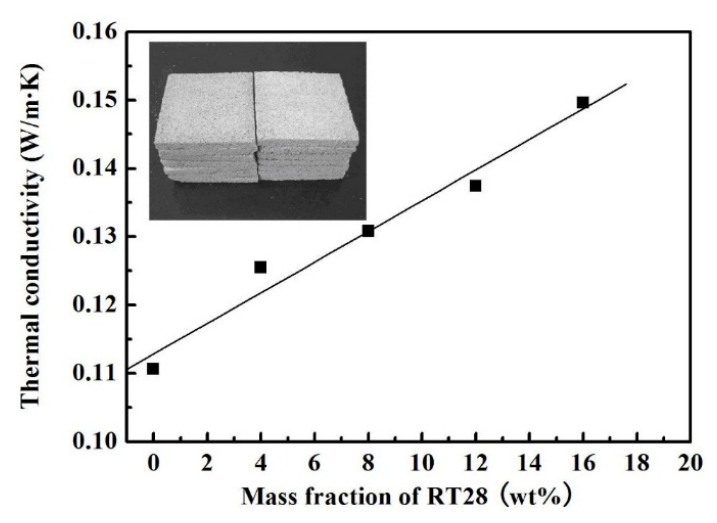

Figure 6. Relation between the thermal conductivity of the boards and the mass fraction of RT28 (the insert is the photograph of the boards). 


\subsection{Thermal Energy Storage Performance of Cement Boards Containing RT28/EP Composites PCMs}

To explore the thermal energy storage performance of the five kinds of boards containing $0,4,8$, 12 and $16 \mathrm{wt} \%$ of RT28, respectively, the test room was set up in two ways. In one way, the test room was set up using six identical boards, in which the mass fractions of RT28 were $0,4,8,12$ and $16 \mathrm{wt} \%$, respectively. In the other way, except the top board, the other five boards of the test room contained no RT28. The boards with $0,4,8,12$ and $16 \mathrm{wt} \%$ of RT28 were used as the top board, respectively.

Figure 7 shows the variations of the temperature differences with time for the test rooms set up using six identical boards containing $0,4,8,12$ and $16 \mathrm{wt} \%$ of RT28, respectively. The temperature difference is defined as the difference of temperature at outside surface of the top board from the indoor temperature of test room. For the test room with the boards containing no RT28, once the light source was switched on, the temperature at the outside surface of the top board increased quickly, resulting in a sharp rise in the temperature difference; $900 \mathrm{~s}$ after the light switching on, the temperature difference got stability around $13{ }^{\circ} \mathrm{C}$; after the light was turned off, the temperature difference quickly dropped to zero. The temperature at the outside surface of the top board was always higher than the indoor temperature during the light switching on, and the maximum temperature difference was calculated to be $13.3^{\circ} \mathrm{C}$. It is revealed that the boards made of cement and EP exhibit the heat insulation capacity to prevent the rapid rise in the indoor temperature.

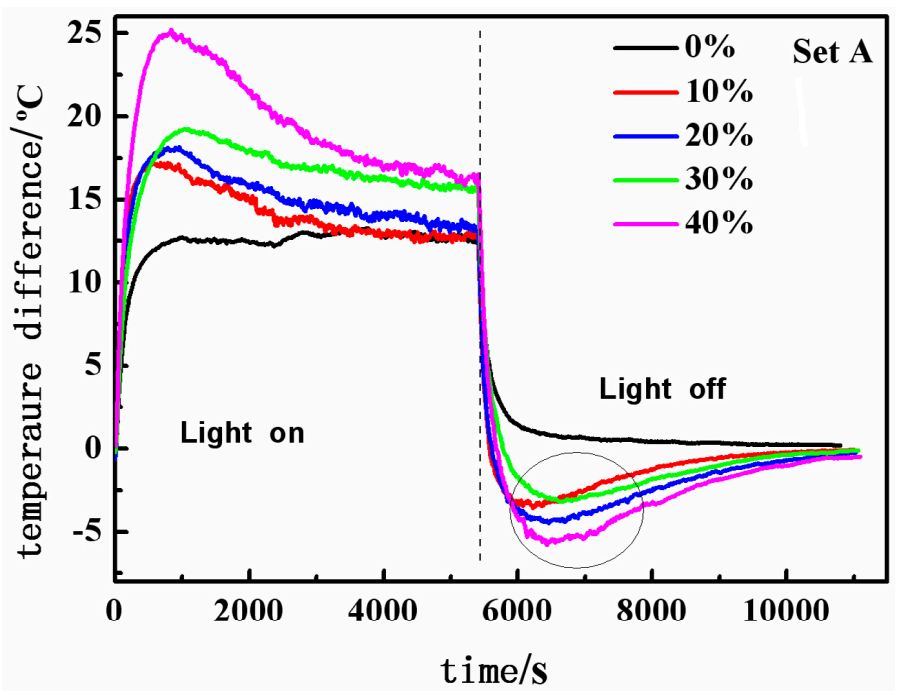

Figure 7. Variations of the temperature differences with time for the five test rooms that consist of six identical boards containing $0,4,8,12$ and $16 \mathrm{wt} \%$ of RT28, respectively (Set A).

It can be also seen from Figure 7 that, the temperature differences in the test rooms that consist of six composite boards are larger than that in the test room with the boards containing no RT28, and the temperature differences increase with the mass fraction of RT28 in the boards. The maximum temperature differences are $17.2,18.2,19.3$ and $25.2^{\circ} \mathrm{C}$ for the test rooms set up using the composite boards containing 4, 8, 12 and $16 \mathrm{wt} \%$ of RT28, respectively, which are higher than $13.3{ }^{\circ} \mathrm{C}$ of the test room with the boards containing no RT28. The bigger the temperature difference, the lower the room temperature. It is revealed that, the incorporation of RT28 into the boards can improve their heat insulation capacity, and the performance enhances with the increase in the mass fraction of RT28. During the illumination of the light source, RT28 integrated into the boards took the phase change from solid state to liquid state by absorbing some amount of heat coming from the light source. Since some heat has been absorbed by RT28, the indoor temperatures of the test rooms set up using the composite boards should be lower than that of the test room set up using the boards without RT28. The amount of the heat absorbed by RT28 is increased with the mass fraction of RT28 in the boards, resulting in the rise in the temperature difference accordingly. More significantly, as 
shown in Figure 7, during the cooling, for every test room that consisted of the composite boards, the temperature at the outside surface of the top board is even lower than the indoor temperature of the test room (as shown with a circle in Figure 7). It is revealed that the composite boards containing RT28 have the function of keeping the test room warm during the cooling, whereas the boards containing no RT28 don't possess the function. The function enhances with the increase in the mass fraction of RT28 in the boards. After the light was switched off, RT28 integrated into the boards took the phase change from liquid state to solid state, and simultaneously released some amount of latent heat. It is reasonable that the indoor temperatures of the test rooms that consist of the composite boards are higher than that of the test room with the boards containing no RT28, owing to the latent heat released by RT28. Since the amount of heat released by RT28 is increased with the mass fraction of RT28 in the boards, the function of keeping the rooms warm enhances accordingly.

Figure 8 shows the variations of the temperature differences with time for the test rooms with the top boards containing $0,4,8,12$ and $16 \mathrm{wt} \%$ of RT28, respectively. It can be seen that the curves in Figure 8 have similar trends to those in Figure 7. During the illumination, the maximum temperature differences for the test rooms with the top boards containing 4, 8, 12 and $16 \mathrm{wt} \%$ of RT28 are 15.2, $16.2,18.2$ and $18.7^{\circ} \mathrm{C}$, respectively, higher than $13.3^{\circ} \mathrm{C}$ of the test room with the boards containing no RT28. It is suggested that the integration of RT28 into the top board of the test room can also exhibit the increase in thermal mass, and the performance gradually enhances with the increase of the mass fraction of RT28. During the cooling, the temperatures at the outside surfaces of the top boards are even lower than the indoor temperatures, indicating that the top boards containing RT28 also exhibit the function of keeping the rooms warm. It is reasonable that, at the same mass fraction of RT28, the test rooms composed of the six composite boards show superior heat insulation capacity to the test room with only the top board containing RT28. The more amount of the PCM is integrated into a building, the better energy conservation performance can be reached.

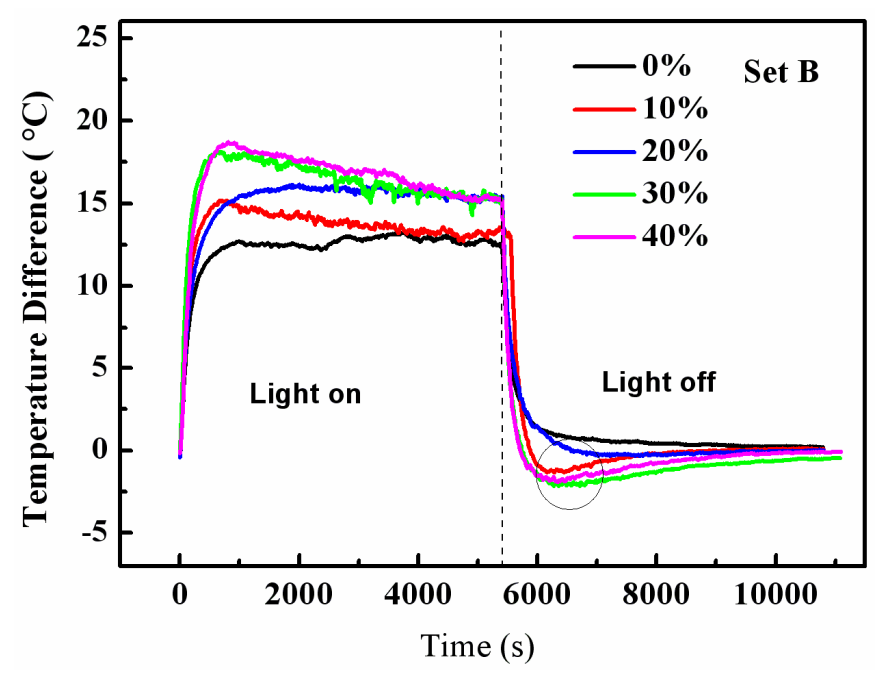

Figure 8. Variations of the temperature differences with time for the five test rooms composed of the top boards containing $0,4,8,12$ and $16 \mathrm{wt} \%$ of RT28, respectively (Set B).

\section{Conclusions}

Form-stable RT28/EP composite PCMs can be obtained by limiting the mass fraction of RT28 no more than $40 \mathrm{wt} \%$. The adsorbed RT28 is observed to be uniformly confined into the pores of EP. The phase change temperatures of the RT28/EP composite PCMs with different mass fractions of RT28 are very close to that of the pure RT28. The latent heat values of the composite PCMs are almost equivalent to the calculated latent heat values based on the mass fractions of RT28. The apparent density and compression strength of the composite cubes increase linearly with the mass fraction of 
RT28. The thermal conductivity of the composite boards increases with the mass fraction of RT28. The composite boards containing RT28 not only exhibit the increase in thermal inertia during the illumination of a light source but also have the function of keeping the test rooms warm after the light source is turned off, which makes the RT/EP composite PCMs show great promise for improving the human comfort and reducing the energy consumption in the buildings.

Acknowledgments: This work is supported by the National Natural Science Foundation of China (No. U1407132), Guangdong Natural Science Foundation (No. 2014A030312009) and the Fundamental Research Funds for the Central Universities (2015ZP006).

Author Contributions: Zhengguo Zhang and Xiaoming Fang conceived and designed the experiments; Rongda Ye performed the experiments; Xuenong Gao analyzed the data; Zhengguo Zhang wrote the paper. All authors read and approved the manuscript.

Conflicts of Interest: The authors declare no conflict of interest.

\section{References}

1. Soares, N.; Costa, J.J.; Gaspar, A.R.; Santos, P. Review of passive PCM latent heat thermal energy storage systems towards buildings' energy efficiency. Energy Build. 2013, 59, 82-103. [CrossRef]

2. Sharma, A.; Tyagi, V.V.; Chen, C.R.; Buddhi, D. Review on thermal energy storage with phase change materials and applications. Renew. Sust. Energy Rev. 2009, 13, 318-345. [CrossRef]

3. Shukla, A.; Buddhi, D.; Sawhney, R.L. Solar water heaters with phase change material thermal energy storage medium: A review. Renew. Sust. Energy Rev. 2009, 13, 2119-2125. [CrossRef]

4. Agyenim, F.; Hewitt, N.; Eames, P.; Smyth, M. A review of materials, heat transfer and phase change problem formulation for latent heat thermal energy storage systems (LHTESS). Renew. Sust. Energy Rev. 2010, 14, 615-628. [CrossRef]

5. Salunkhe, P.B.; Shembekar, P.S. A review on effect of phase change material encapsulation on the thermal performance of a system. Renew. Sust. Energy Rev. 2012, 16, 5603-5616. [CrossRef]

6. Baetens, R.; Jelle, B.P.; Gustavsen, A. Phase change materials for building applications: A state-of-the-art review. Energy Build. 2010, 42, 1361-1368. [CrossRef]

7. Cabezaa, L.F.; Castell, A.; Barrenechea, C.; De Graciaa, A.; Fernández, A.I. Materials used as PCM in thermal energy storage in buildings: A review. Renew. Sust. Energy Rev. 2011, 15, 1675-1695. [CrossRef]

8. Parameshwarana, R.; Kalaiselvamb, S.; Harikrishnanb, S.; Elayaperumala, A. Sustainable thermal energy storage technologies for buildings: A review. Renew. Sust. Energy Rev. 2012, 16, 2394-2433. [CrossRef]

9. Kuznik, F.; David, D.; Johannes, K.; Roux, J.J. A review on phase change materials integrated in building walls. Renew. Sust. Energy Rev. 2011, 15, 379-391. [CrossRef]

10. Sá, A.V.; Azenha, M.; de Sousa, H.; Samagaio, A. Thermal enhancement of plastering mortars with phase change materials: Experimental and numerical approach. Energy Build. 2012, 49, 16-27. [CrossRef]

11. Borreguero, A.M.; Luz, S.M.; Valverde, J.L.; Carmona, M.; Rodríguez, J.F. Thermal testing and numerical simulation of gypsum wallboards incorporated with different PCMs content. Appl. Energy 2011, 88, 930-937. [CrossRef]

12. Hawes, D.W.; Feldman, D. Absorption of phase change materials in concrete. Sol. Energy Mater. Sol. Cells 1992, 27, 91-101. [CrossRef]

13. Hadjieva, M.; Stoykov, R.; Filipova, T. Composite salt-hydrate concrete system for building energy storage. Renew. Energy 2000, 19, 111-115. [CrossRef]

14. Lee, T.; Hawes, D.W.; Banu, D.; Feldman, D. Control aspects of latent heat storage and recovery in concrete. Sol. Energy Mater. Sol. Cells 2000, 62, 217-237. [CrossRef]

15. Athienitis, A.K.; Liu, C.; Hawes, D.; Banu, D.; Feldman, D. Investigation of the thermal performance of a passive solar test-room with wall latent heat storage. Build. Environ. 1997, 32, 405-410. [CrossRef]

16. Rudd, A.F. Phase-change material wallboard for distributed thermal storage in buildings. ASHRAE Trans. 1993, 99, 339-346.

17. Schossig, P.; Henning, H.M.; Gschwander, S.; Haussmann, T. Microencapsulated phase-change materials integrated into construction materials. Sol. Energy Mater. Sol. Cells 2005, 89, 297-306. [CrossRef]

18. Cabeza, L.F.; Castellón, C.; Nogués, M.; Medrano, M.; Leppers, R.; Zubillaga, O. Use of microencapsulated PCM in concrete walls for energy savings. Energy Build. 2007, 39, 113-119. [CrossRef] 
19. Tyagi, V.V.; Kaushik, S.C.; Tyagi, S.K.; Akiyama, T. Development of phase change materials based microencapsulated technology for buildings: A review. Renew. Sust. Energy Rev. 2011, 15, 1373-1391. [CrossRef]

20. Arce, P.; Castellón, C.; Castell, A.; Cabeza, L.F. Use of microencapsulated PCM in buildings and the effect of adding awnings. Energy Build. 2012, 44, 88-93. [CrossRef]

21. Hunger, M.; Entrop, A.G.; Mandilaras, I.; Brouwers, H.J.H.; Founti, M. The behavior of self-compacting concrete containing micro-encapsulated phase change materials. Cem. Concr. Compos. 2009, 31, 731-743. [CrossRef]

22. Zhang, Y.P.; Lin, K.P.; Yang, R.; Di, H.F.; Jiang, Y. Preparation, thermal performance and application of shape-stabilized PCM in energy efficient buildings. Energy Build. 2006, 38, 1262-1269. [CrossRef]

23. Sari, A.; Biçer, A. Thermal energy storage properties and thermal reliability of some fatty acid esters/building material composites as novel form-stable PCMs. Sol. Energy Mater. Sol. Cells 2012, 101, 114-122. [CrossRef]

24. Kenisarin, M.M.; Kenisarina, K.M. Form-stable phase change materials for thermal energy storage. Renew. Sust. Energy Rev. 2012, 16, 1999-2040. [CrossRef]

25. Sari, A. Form-stable paraffin/high density polyethylene composites as solid-liquid phase change material for thermal energy storage: preparation and thermal properties. Energy Convers. Manag. 2004, 45, 2033-2042. [CrossRef]

26. Zhang, Z.G.; Fang, X.M. Study on paraffin/expanded graphite composite phase change thermal energy storage material. Energy Convers. Manag. 2006, 47, 303-310. [CrossRef]

27. Fang, X.M.; Zhang, Z.G.; Chen, Z.H. Study on preparation of montmorillonite-based composite phase change materials and their applications in thermal storage building materials. Energy Convers. Manag. 2008, 49, 718-723. [CrossRef]

28. Karaipekl, A.; Sari, A. Capric-myristic acid/vermiculite composite as form-stable phase change material for thermal energy storage. Sol. Energy 2009, 83, 323-332. [CrossRef]

29. Mei, D.D.; Zhang, B.; Liu, R.C.; Zhang, Y.T.; Liu, J.D. Preparation of capric acid/halloysite nanotube composite as form-stable phase change material for thermal energy storage. Sol. Energy Mater. Sol. Cells 2011, 95, 2772-2777. [CrossRef]

30. Karaman, S.; Karaipekli, A.; Sar, A.; Biçer, A. Polyethylene glycol (PEG)/diatomite composite as a novel form-stable phase change material for thermal energy storage. Sol. Energy Mater. Sol. Cells 2011, 95, 1647-1653. [CrossRef]

31. Chen, Z.; Shan, F.; Cao, L.; Fang, G.Y. Preparation and thermal properties of $n$-octadecane/molecular sieve composites as form-stable thermal energy storage materials for buildings. Energy Build. 2012, 49, 423-428. [CrossRef]

32. Wang, Y.; Xia, T.D.; Feng, H.X.; Zhang, H. Stearic acid/polymethylmethacrylate composite as form-stable phase change materials for latent heat thermal energy storage. Renew. Energy 2011, 36, 1814-1820. [CrossRef]

33. Won, J.P.; Kang, H.B.; Lee, S.J.; Lee, S.W.; Kang, J.W. Thermal characteristics of high-strength polymer-cement composites with lightweight aggregates and polypropylene fiber. Constr. Build. Mater. 2011, 25, 3810-3819. [CrossRef]

34. Karaipekli, A.; Sari, A. Capric-myristic acid/expanded perlite composite as form-stable phase change material for latent heat thermal energy storage. Renew. Energy 2008, 33, 2599-2605. [CrossRef]

35. Sari, A.; Karaipekli, A.; Alkan, C. Preparation, characterization and thermal properties of lauric acid/expanded perlite as novel form-stable composite phase change material. Chem. Eng. J. 2009, 155, 899-904. [CrossRef]

36. Karaipekli, A.; Sari, A.; Kaygusuz, K. Thermal characteristics of paraffin/expanded perlite composite for latent heat thermal energy storage. Energy Sources A 2009, 31, 814-823. [CrossRef]

37. Jiao, C.G.; Ji, B.H.; Fang, D. Preparation and properties of lauric acid-stearic acid/expanded perlite composite as phase change materials for thermal energy storage. Mater. Lett. 2012, 67, 352-354. [CrossRef]

38. Chung, O.; Jeong, S.G.; Kim, S. Preparation of energy efficient paraffinic PCMs/expanded vermiculite and perlite composites for energy saving in buildings. Sol. Energy Mater. Sol. Cells 2015, 137, 107-112. [CrossRef] 
39. Zhang, N.; Yuan, Y.P.; Yuan, Y.G.; Li, T.Y.; Cao, X.L. Lauric-palmitic-stearic acid/expanded perlite composite as form-stable phase change material: Preparation and thermal properties. Energy Build. 2014, 82, 505-511. [CrossRef]

40. Sun, D.; Wang, L.J.; Li, C.M. Preparation and thermal properties of paraffin/expanded perlite composite as form-stable phase change material. Mater. Lett. 2013, 108, 247-249. [CrossRef]

41. Ramakrishnan, S.; Sanjayan, J.; Wang, X.M.; Alam, M.; Wilson, J. A novel paraffin/expanded perlite composite phase change material for prevention of PCM leakage in cementitious composites. Appl. Energy 2015, 157, 85-94. [CrossRef]

42. Peng, K.; Zhang, J.Y.; Yang, H.M.; Ouyang, J. Acid-hybridized expanded perlite as a composite phase-change material in wallboards. RSC Adv. 2015, 81, 66134-66140. [CrossRef]

43. Zhang, J.W.; Guan, X.M.; Song, X.X.; Hou, H.H.; Yang, Z.P.; Zhu, J.P. Preparation and properties of gypsum based energy storage materials with capric acid-palmitic acid/expanded perlite composite PCM. Energy Build. 2015, 92, 155-160. [CrossRef]

44. He, Y.; Zhang, X.; Zhang, Y.J. Preparation technology of phase change perlite and performance research of phase change and temperature control mortar. Energy Build. 2014, 85, 506-514. [CrossRef]

45. Standard for Test Method of Performance on Building Mortar; Chinese Standard: JGJ/T 70-2009; China Architecture \& Building Press: Beijing, China, 2009.

46. Borreguero, A.M.; Garrido, I.; Valverde, J.L.; Rodríguez, J.F.; Carmona, M. Development of smart gypsum composites by incorporating thermoregulating microcapsules. Energy Build. 2014, 76, 631-639. [CrossRef]

(C) 2015 by the authors; licensee MDPI, Basel, Switzerland. This article is an open access article distributed under the terms and conditions of the Creative Commons by Attribution (CC-BY) license (http:/ / creativecommons.org/licenses/by/4.0/). 